\title{
Reform and Practice of Cultivating Talents Majoring in Mechanical Design, Manufacturing and Automation in Local Application-oriented Institutions
}

\author{
Cao Guangming; Jiang Junsheng; Wang Changchun; Zhang Peng \\ Weifang University, \\ Weifang, Shan Dong, 261061
}

\begin{abstract}
Based on the requirement of high-qualified applied talents by the Shandong "Blue and Yellow" Regional Economic Construction Strategy, the mechanical design, manufacturing and automation specialty of Weifang University, fastens on a notion of the democratic ideals of openness, strengthens the School-enterprise cooperation, innovates personnel training mode and deepens the construction of practical teaching and innovative educational mechanism, thus exploring a new path of training for applied talents.
\end{abstract}

Keywords -application-oriented institutions; talent cultivation; cooperative education; cultivate people with innovation; practice teaching

\section{INTRODUCTION}

According to the new requirements of higher education and personnel training from the National Outline for Medium and Long-term Education Reform and Development (2010-2020) and Shandong "Blue and yellow" Regional Economic Development Strategy, Weifang University, as a local application-oriented regular institution, strengthens cooperation between school and enterprise actively, continuously innovates cooperation mode and in-depth advances reform and practice of education and teaching. As a consequence, a new method of cultivating applied talents was explored.

\section{GUIDING THE TEACHING REFORM PRACTICE BY DEMANDS}

\section{FOR TALENTS IN THE SHANDONG "BLUE AND YELLOW"}

\section{REGIONAL ECONOMIC CONSTRUCTION}

Weifang is an important industrial base of Shandong Province. It is also an important industrial base of internal combustion engines, light vehicles, construction machinery and agricultural equipment [1]. In recent years, there have appeared a lot of big transnational corporations with strong competitiveness, such as Weichai Power, Futon Lovol International Heavy Industry Co., Ltd. and Goertek Co., Ltd., which are very influential at home and abroad. According to the general requirements of "Transferring Mode, Adjusting Structure" strategy issued by the country, Shandong Province proposed a strategic plan of creating a peninsula blue economic zone and the Yellow River Delta High-Efficiency Eco-Economic Zone (hereinafter referred to as "Blue and Yellow" districts). With the support of national industrial policy, speeding up the pace of structural adjustment and industrial upgrading, improving the grade of product, constantly creating and process technology development, advancing core competence, fostering new sources of economic growth and strengthening the economic comprehensive strength, there will be a higher demand for application-oriented high-level technical talents as well as managerial and administrative personnel.

In combination with the reform and development, personnel training of the mechanical design, manufacturing and automation specialty (hereinafter referred to as mechanical manufacture specialty), Weifang University visited a large number of industries and enterprises and obtained the first-hand information about the demand for job employment. The investigation helps to further define the classification of the talents cultivation and general requirements of the mechanical manufacture specialty and adjust the curriculum design oriented to industry. Rather than putting much emphasis on the systematization and integrity of course knowledge system, Weifang University tries to create a knowledge system based on the latest development of the industry, which can not only adapt the requirement of the position, but also have a certain capacity for sustainable development. In the course of developing students' creative and practical abilities, Weifang University stresses the importance of cultivating senior professionals of technical application, focuses on training the students' comprehensive abilities of analyzing and solving problems, and strengthens the innovative application of existing knowledge. At the same time, taking the market demand as the direction, Weifang University centers on training high-level specialized talents from all industries, especially pays great attention to those who can grasp a strong ability of organization and coordination, the language and intercultural communication competence, 
comprehensive utilization ability as well as social adaptability[2].

In support of these training objectives, an opening and cooperative running college mode must be introduced to enhance contact and coordination and establish a new cooperation mechanism with industries and enterprises to cultivate application-type personnel. Furthermore, conducting cooperation between college and enterprise is a very effective way to train personnel to serve and fit for society. This kind of education mode has successfully cultivated a large number of talents that are able to satisfy the demand of the economic development and promote the development of the "Blue and Yellow" regional economy and industry.

\section{MAKING INNOVATION ON COOPERATION MODEL,} PROMOTING DEVELOPMENT OF THE THREE COOPERATION AND ESTABLISHING MECHANISM AND ENVIRONMENTAL CONDITIONS

\section{TO CULTIVATE APPLICATION-ORIENTED TALENTS WITH HIGH}

\section{QUALITIES}

\section{A. Strengthening cooperation with Goertek Co., Ltd. and co-creating the "Goer Mode" with school-enterprise cooperation}

Goertek Co., Ltd. (hereinafter referred to "Goer") is a national high-tech enterprise, and also a new, modern one which supported by the state. Goer is now a great corporation with huge potential, promising prospects and high employment demand. The school sets up specialized course and forms a specialized training class combined with Goer. Based on the order-type personnel training mode, the school signs agree with Goer and Weifang high-tech industrial development zone, creating a "Goer Mode" and making the school-enterprise cooperation even further.

The personnel training plan is developed by school and enterprise together, which is called " $\mathrm{X}+2$ " talents cultivation model. In the first two years, the school is in charge of the training plan, mainly teaching the basic courses. Goer designs the rest part of the teaching plan, which includes specialized courses and practical teaching. The school has the outstanding teaching staff were primarily responsible for the teaching task. In addition, Goer selected a team of highly qualified technical backbones to work as part-time teachers, taking charge of specialized courses and practical teaching tasks.

In practices, the school set up a special operational mechanism and school-running model which can be regarded as "Five-in-one" involving the practical teaching base, teaching work, scientific research, admissions and employment. Weifang University and Goer have realized cooperative construction of the engineering practical education center. It is one of the first programs called "Regular College Teaching Project" of the college students with practical teaching base among regional colleges approved by the Ministry of Education. With the purpose of awarding excellent students, Goer Scholarship has been founded, and students who graduate from the specialized training class of Goer can be employed in priority by Goer. At present, the school has set up rules and regulations and specific operational norms of school-enterprise running model, and has explored innovative student management based on the cooperation between school and enterprise. Besides that, from the students' perspective, each year the school gives a chance to the student who is qualified to adjust the major direction and trained in the model of "X+2", according to the development of Goer.

\section{B. Adherence to cooperating with Weichai Power Co, Ltd and co-constructing "Weichai Model" of engineering specialty}

Weifang University has signed up to the agreement of school-enterprise cooperation with Weichai Power, promising to build the Specialty of Mechanical Mechanism in company. Under leadership of school and Weichai Power, a cooperation council and a joint working group have been set up, which on purpose, to formulate the training objective and talents training plan altogether. Also, they are expected to take charge of the construction of the practical teaching base as well as the organization and operation of teaching activities.

In practical teaching, the implementation of the binary tutor system can greatly cultivate students' engineering ability. From the 3rd semester on, students can start professional investigation in the company. In the 5th semester, enterprises send excellent engineering and technical students to work as extramural instructors, providing necessary guidance or training for students. On the one hand, this helps students to experience and feel the corporate culture; On the other hand, it benefits the enterprise by discovering, cultivating and retaining talents. When the 7th semester comes, the students are ready to start their production practice. During this period, manufactures schedule work for students according to the requirements of "Trainee Assistant Engineer", giving strict guidance, supervision and assessment. In the 8th semester, under the guidance of tutors both inside and outside the school, combined with the actual production of the enterprise, they choose posts like Engineering Technician and Production Controller as main practice object, take the resolution of practical problems as the topic of the graduation design and finish the graduation design.

The binary tutor system can immensely motivate the construction of teaching body of "dual-qualified teachers"[3]. Each year young teachers are selected and sent to "Weichai" receiving exercises, getting involved in product research and technical and scientific activities. In the meanwhile, senior engineering and technical personnel from "Weichai" are employed as part-time professors to undertake some practical teaching tasks. The development of "dual-qualified teachers" teaching body offers a solid basis for specialized teaching.

\section{Adherence to cooperating with Qingdao Yinggu Education and Technology Co, .Ltd and establishing a new pattern of " $3+1$ " mode}

According to the 10-year development plan of Made in China 2025, the intelligent equipment manufacturing industry will have a greater and faster development in the future [4]. Based on the urgent needs of application-oriented talents 
majoring in intelligent design and intelligent control, the school cooperates with Qingdao Yinggu Education and Technology Co., $\operatorname{Ltd}($ hereinafter referred to "Qingdao Yinggu"), sets up the specialty of Intelligent Manufacturing and Industrial Information, discusses the reform of teaching content and course system with Qingdao Yinggu and draws up the talent training program.

In the light of the " $3+1 "$ cooperative mode for training talents, the students study at school in the first three years in order to finish general education curriculum, basic courses and specialized courses. Teaching tasks of this period are supposed to be led by school. In the 4th year, students begin their training projects in accordance with the enterprise' situation, complete the graduation design under the "dual-qualified teachers" teaching model. And during this period, Qingdao Yinggu is responsible for the teaching plan.

The "3+1" model provides a seamless platform for school-enterprise cooperation. In line with the cultivation idea of highlighting the application, strengthening the technological advantage, emphasizing the combination of production and study and noticing school-enterprise cooperation, the school sets up the disciplines and adjusts major directions according to the market demand, stresses the teaching and employment in terms of practice. In this way, the adaption period between new staff and enterprise is greatly reduced and large numbers of highly qualified, application-oriented talents with strong practical ability have come to the job market.

\section{ADHERENCE TO IMPLEMENTING THE THREE COOPERATION,}

\section{COMPREHENSIVELY REVISING OF THE TALENTS CULTIVATION}

\section{PROGRAM AND INNOVATING TALENTS TRAINING MODE}

In accordance with the high qualified and application-oriented talents cultivation orientation, combined with the three cooperation above, the school constantly revises the talents training plan, moderately reduces the theory courses, strengthens practice teaching, develops the curriculum system the teaching contents with modularity and flexibility, cultivates and educates students classifiably. Exploring in practice, the school has established the talents training model of "Three Combinations, One Prominence", which is of great characteristics of application-oriented institutions [5].

One is about "The combination of industry, universities and research institution". This kind of new pattern contributes to the use of external high-quality educational resources and the construction of practical teaching base. Based on the operative mechanism of opening education, organically combining classroom instruction with productive process and technical innovation, in this way the students' ability of suiting the society and competitiveness of employment are greatly improved.

The second is "The integrity of theory with practice". The school has successfully constructed the practical education system beneficial to the application-oriented talents and this is in parallel with teaching. The model theory-practice-re-theory-re-practice helps the students learn by practicing and practice by learning. Such research avoids the discrepancy of theory and practice and has got a remarkable achievement.

The third is "In-class teaching in combination with after-class activities". In order to realize the coordinated development of human beings' overall qualities, the school carries out a lot of extra-curricular training activities, including reading activities, holding seminars and academic lectures, organizing academic competitions and developing social investigation and practice. Thanks to the extracurricular guidance system, students' scientific spirit and humanistic quality are improved. And this also promotes the comprehensive development of students.

"One Prominence" means giving prominence to the cultivation of the students' professional practical ability and overall quality with innovation at its core, which occurs throughout the whole process of the talents training plan.

\section{ADHERENCE TO IMPROVING THE CONDITIONS OF PRACTICE} TEACHING AND THE CONSTRUCTION OF OPERATING

\section{MECHANISM, CULTIVATING THE PROFESSIONAL PRACTICAL}

\section{ABILITIES OF THE STUDENTS}

The school sets up four practical teaching platforms to enhance the students' professional practical ability.

1) Off-campus practical teaching platform. Represented by Weichai Power, Goer and Qingdao Yinggu, these platforms provide favorable engineering practice surrounding for the students, gives them chances to be assigned to the forefront of production, to visit and participate in the manufacturing process. This can help cultivate students' professional applying abilities and finish the graduation design.

2) On-campus mechanical and electrical engineering training platform. For the purpose of engineering practice ability, the school equips with an engineering training center involving sophisticated equipment, complete types of work, teaching, scientific research, production and practice.

3) University Scientific and technology Innovation Platform. By establishing the college students' technology innovation laboratory, constructing and improving mechanisms, the school gives expenditure guarantee and policy guidance, strives to offer good conditions for innovation practice.

4) Platforms for skills identification and skill certification. Making use of the campus practice and resources of school-enterprise cooperation, the school has started work of skills identification represented by numerically-controlled machine tool programming and operation, as well as work of skill certification represented by CAD/CAM skills.

On the basis of the construction of the practical platform, the school improves teaching method and carries out the "Five-way, Five-step" teaching method. Five-way refers to learning styles that based more on autonomy, cooperation, guidance, instruction and research; Five-step teaching method is all about teaching approaches including theory explanation, 
project to design, practices guidance, practical training and comprehensive assessment.

In the practical teaching, it is very necessary to adhere to "Six-aspect integration" practice teaching mode. To be more specific, it usually means the combination of machine and electricity, of engineering practice and engineering quality cultivating, of practical teaching and practical application of enterprise, of practical contents and product manufacturing process, of traditional practice and modern manufacturing technology, of skill training and innovative practice. All these are conducive to achieving the comprehensive development of student engineering practice ability.

\section{ADHERENCE TO OPTIMIZING THE INNOVATIVE EDUCATION}

\section{SYSTEM, DEVELOPING ALL KINDS OF DISCIPLINE}

\section{COMPETITIONS, CULTIVATING STUDENTS' INNOVATIVE \\ PRACTICAL ABILITY}

The cultivation of innovative practical ability is an important part of training application-oriented talents. Discipline competitions are effective ways to integrate practical teaching links in and out of the class, cultivate students' innovative practical ability [6]. At present, there exists a series of competitions consisting of Student Research Training Program (SRTP), Electromechanical Creative Design Competition at or above province level, Engineering Training Comprehensive Ability Contest, 3D Digitalization Design Competition and Challenge Cup, etc. It realizes the connecting and cooperation among competitions at school-level, provincial-level and state-level.

When building the mechanism for innovative cultivation, the school sets up virtual staff room, establishes students' creative department, builds an innovation tutors' repository, carries out the system of tutor-in-charge innovation projects, pays attentions to awarding innovation and forms an educational mechanism with stimulation on innovative practice.

Innovation Education can not only give a major push to the cultivation of innovative spirit and innovative ability of the students, but also become distinct features in the process of training high qualified application-oriented personnel.

\section{CONCLUSION}

Seeing from the former reforming practice, the talent training program got thoroughly implemented, and the results showed the program is scientific and reasonable. All the reform measures in personnel training mode and personnel training process got fully implemented, the actual operation results were good, and in practice continued to be perfect and optimized.
Over the past four years, the satisfaction result of the following service was $100 \%$, university IT pass rate hit $100 \%$, the cumulative passing rate of CET4 got to be $99.4 \%$, the rate of taking post-graduate entrance examination reached $20 \%$ or more, graduation rate reached $99.5 \%$, degree award rate, $98.1 \%$, and the excellent rate of graduation thesis (designs) reached $15.7 \%$. Students all participated in the NC technical professional job skills training, more than $60 \%$ of the students participated in the AutoCAD, ProE and other vocational skills training and achieved the vocational qualification certificate. The professional ability of students were significantly improved. Students participated in the provincial level contest on various disciplines contest and got 123 awards, of which 7 national awards and 15 authorized patents, the ability of innovation and innovation of students got significantly enhanced. In the latest three years, the employment rate of students surpassed $97 \%$, the rate of applying and the quality of students was getting better and better, and the social reputation continued to improve.

Next step, with the deepening of school-enterprise cooperation, the mode of personnel training will continue to be improved, the practical teaching and innovative education shall be strengthened, and the quality of personnel training shall be further enhanced to meet the demand for high-quality applied talents of regional economic construction. Meanwhile, good demonstration will be provided for talent training in colleges and universities.

\section{REFERENCES}

[1] Mingming Du. Study of Industry Development and Environmental Effect of Weifang from the Yellow River Delta High-efficiency Eco-economic Zone and the Blue Economic Zone construction [D]. Qilu University of Technology, 2013. (In Chinese)

[2] Guangming Cao. Teaching Research and Reform Practice for Training Innovation Applied Talents[C]. 2nd Teaching Seminars on Higher Education Science and Engineering Courses, 2012:531-535. (In Chinese)

[3] Yong Wang, Shanshan Su, Hequan Shan. The Research of the Connotation and the Problems Existing for Double-qualified Teachers [J]. Human Resource Management, 2017, (02) : 134-135. (In Chinese)

[4] Xueman Su, Lili Sun. The New Demand for Manufacturing Talents under the Background of China Manufacturing 2025[J]. The Science Education Article Collects (midmonth), 2016, (02) : 64-65. (In Chinese)

[5] Jianguo Zou, Jiezhi Yan. The Plights and Outlets of Talent Training Mode for Local Undergraduate Colleges Under the Background of Transformation and Development [J].Journal of Higher Education, 2017, (04) : 150-151. (In Chinese)

[6] Xiu Shen, Rongfang Sui, Dewei Zeng. Construction and Practice of Discipline Contest Management System in Local Universities [J]. Research and Exploration in Laboratory, 2014, (11) : 187-190+277. (In Chinese) 